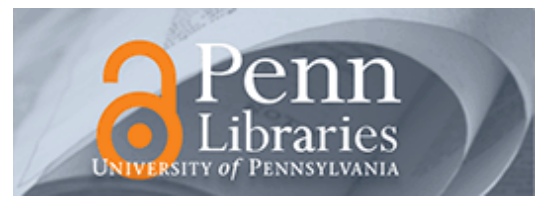

University of Pennsylvania

ScholarlyCommons

Accounting Papers

Wharton Faculty Research

$12-2011$

\title{
Corporate Governance and the Information Content of Insider Trades
}

\author{
Alan D. Jagolinzer \\ David F. Larcker \\ Daniel J. Taylor \\ University of Pennsylvania
}

Follow this and additional works at: https://repository.upenn.edu/accounting_papers

Part of the Accounting Commons

\section{Recommended Citation}

Jagolinzer, A. D., Larcker, D. F., \& Taylor, D. J. (2011). Corporate Governance and the Information Content of Insider Trades. Journal of Accounting Research, 49 (5), 1249-1274. http://dx.doi.org/10.1111/ j.1475-679X.2011.00424.x

This paper is posted at ScholarlyCommons. https://repository.upenn.edu/accounting_papers/22

For more information, please contact repository@pobox.upenn.edu. 


\title{
Corporate Governance and the Information Content of Insider Trades
}

\author{
Abstract \\ Most corporate governance research focuses on the behavior of chief executive officers, board members, \\ institutional shareholders, and other similar parties. Little research focuses on the impact of executives \\ whose primary responsibility is to enforce and shape corporate governance inside the firm. This study \\ examines the role of the general counsel (GC) in mitigating informed trading by corporate insiders. We \\ find that insider trading profits and the predictive ability of insider trades for future operating performance \\ are generally higher when insiders trade within firm-imposed restricted trade windows. However, when GC \\ approval is required to execute a trade, insiders' trading profits and the predictive ability of insider trades \\ for future operating performance are substantively lower. Thus, when given the authority, it appears the \\ GC can effectively limit the extent to which corporate insiders use their private information to extract \\ rents from shareholders. \\ Disciplines \\ Accounting
}




\title{
Corporate Governance and the Information Content of Insider Trades
}

\author{
Alan D. Jagolinzer \\ jagolinzer@colorado.edu \\ Leeds School of Business \\ University of Colorado \\ David F. Larcker \\ larcker_david@gsb.stanford.edu \\ Graduate School of Business \\ Rock Center for Corporate Governance \\ Stanford University
}

Daniel J. Taylor

dtayl@wharton.upenn.edu

The Wharton School

University of Pennsylvania

June 2011

\footnotetext{
We thank William Beaver, Maureen McNichols, Abbie Smith (editor), two anonymous referees, and seminar participants at Stanford University for comments and suggestions. We also thank the Society of Corporate Secretaries and Governance Professionals, The Rock Center for Corporate Governance, and the Corporate Governance Research Program at Stanford University for providing a portion of the data used in this paper. We thank John Johnson and Ravi Pillai for extensive programming help. Daniel Taylor gratefully acknowledges financial support from the Deloitte Foundation.
} 


\title{
Corporate Governance and the Information Content of Insider Trades
}

\begin{abstract}
:
Most corporate governance research focuses on the behavior of chief executive officers, board members, institutional shareholders, and other similar parties. Little research focuses on the impact of executives whose primary responsibility is to enforce and shape corporate governance inside the firm. This study examines the role of the general counsel in mitigating informed trading by corporate insiders. We find that insider trading profits and the predictive ability of insider trades for future operating performance are generally higher when insiders trade within firm-imposed restricted trade windows. However, when general counsel approval is required to execute a trade, insiders' trading profits and the predictive ability of insider trades for future operating performance are substantively lower. Thus, when given the authority, it appears the general counsel can effectively limit the extent to which corporate insiders use their private information to extract rents from shareholders.
\end{abstract}

JEL Classification: G34, J33, K31, M52

Keywords: corporate governance, insider trading, insider trading policies, general counsel, restricted trade windows 


\section{Corporate Governance and the Information Content of Insider Trades}

\section{Introduction}

There is a vast empirical literature that examines the relation between corporate governance and firm performance, executive compensation, operating decisions, and financing decisions (e.g., Gompers et al, 2003; Holmstrom and Kaplan, 2003). Most of this research examines the association between characteristics of the board of directors, institutional investors, and the extent to which managers extract rents from corporate shareholders. This literature has used plausible, but relatively imprecise measures for corporate governance (e.g., "G-score", percentage of the board that is independent, board size, presence of an "accounting expert", etc.) and the empirical results are quite mixed (e.g., Bhagat and Black, 1998; Core et al., 2006; Larcker et al, 2007).

One particular issue with this literature is that there is scant evidence on the mechanism by which governance is executed within the firm. For example, assuming that busy board members are less valuable monitors (e.g., Fich and Shivdasani, 2006), what specific actions do busy board members take (or not take) that cause the board to be ineffective? Similarly, what specific actions do "accounting experts" take that increase the effectiveness of the audit committee? Even if such actions can be specified, they are unlikely to be directly observable. In this paper, we examine the impact of the firm's internal control process - specifically, actions taken by the general counsel - on addressing one specific governance issue, namely mitigating the level of informed trade. If informed trading by insiders is considered undesirable by shareholders or 
illegal by regulators, corporate governance should manifest itself in effective trading restrictions. $^{1}$

Although prior work has extensively examined the behavior of corporate officers such as the chief executive officer (CEO), little is known about the role of the individual executives whose responsibility it is to shape and monitor corporate governance within the firm. The general counsel's primary responsibilities include being the legal adviser to the firm, supervisor of inhouse legal team, assessing litigation risk, evaluating compliance with regulatory rules, and dealing with various third parties (DeMott, 2005). The general counsel (GC) is sometimes viewed as the "ethics police person" to catch inappropriate activities and institute corrective actions to bring the rule-breaker into compliance with corporate governance standards (Winders, 2005). The GC is also a key member of the committees that examine the adequacy of internal controls and compliance with regulatory rules. Thus, the GC occupies an important position for establishing and maintaining governance procedures within the firm. ${ }^{2}$

If the general counsel actively governs insiders' transactions to mitigate informed trade, we expect to observe restrictive governance elements within the firm's insider trade policy (ITP). However, an alternative hypothesis is that the formal governance elements contained in the ITP are simply "cheap-talk" or "window dressing." That is, the firm may simply claim that they

\footnotetext{
${ }^{1}$ In a related study, Ravina and Sapienza (2010) measure governance using G-score and board size, and find that insiders earn higher trading profits at firms with the "weakest" governance. Although this suggests there is an association between governance and insiders' trading profits, the underlying mechanism behind this association is still not clear.

${ }^{2}$ It is possible that personal ethics and professional standards (and the risk of being disbarred) provide sufficient motivation for the GC to always take the necessary actions to maintain a high level of corporate governance. However, the appointment of and the compensation paid to the GC are typically approved by the senior officers of the firm (e.g., the GC generally reports to either the chief executive or chief financial officer). As a result, it is not clear whether the GC will always actively monitor and evaluate management's decision making process. For example, the GC at Enron ignored the conflict of interest posed by special-purpose-entity transactions in which the CFO had a vested financial interest (Batson, 2003; DeMott, 2005). Additionally, approximately 30\% of the GCs at firms where the SEC has filed civil and/or criminal backdating charges have been terminated. These examples suggest that at least some GCs have been either complicit or have failed to institute appropriate internal controls.
} 
restrict informed trading, but may deviate from this rule in practice or the general counsel may act as a "rubber stamp" for insider trades.

In order to investigate the effectiveness of the governance provisions in the ITP at mitigating informed trade, we examine the trades made by Section 16 insiders where we know the precise terms of the firm's ITP. ${ }^{3}$ It is illegal for insiders to trade while in possession of material nonpublic information (Securities and Exchange Acts of 1933 and 1934; Insider Trading Sanctions Act of 1984 (ITSA); Insider Trading and Securities Fraud Enforcement Act of 1988 (ITSFEA)). However, prior research finds that insiders do appear to place, and profit from, trades based on superior information (e.g., Aboody and Lev, 2000; Ke et al. 2003; Piotroski and Roulstone, 2005; Huddart et al., 2007; Ravina and Sapienza, 2010). Building on these studies, we test the effectiveness of governance provisions in the ITP by examining whether such provisions are associated with (decreased) insider trading profits and the ability of insiders' trades to predict future operating performance.

Our analysis focuses on elements of firms' ITPs that allow us to infer the degree of GC control over the trading environment. Specifically, we focus on the terms of the firm's restricted trading window and whether the ITP states that GC approval is required for any insider transaction. We find that $80 \%$ of our sample firms require trades to be pre-approved by the general counsel, and the average length of restricted trading windows is 48 days (46 days before and 1 day after an information event). Interestingly, and in contrast to prior literature (e.g., Bettis et al., 2000), we find that about $24 \%$ of all insider trades occur within restricted trade windows.

\footnotetext{
${ }^{3}$ Section 16(b) of the Securities and Exchange Act of 1934 provides guidance regarding purchases and sales of securities by firm officers and directors. Officers and directors are often referred to as "Section 16 insiders". We refer to these individuals as "insiders" for the remainder of the paper.
} 
We find that active monitoring by the general counsel is associated with a substantial reduction in informed trading by insiders and the extent to which insiders use their private information to extract rents from shareholders. On average we find that insider trades that do not require GC approval earn risk-adjusted returns of $0.03 \%$ per day, but when general counsel is required such trades earn $-0.01 \%$ per day, a difference of $0.04 \%$ or $7.20 \%$ over the 180 days following the trade. Additionally, and consistent with prior work, we find that net purchases of insiders positively predict future earnings surprises. However, consistent with the GC reducing the level of informed trade, we find that only those trades not approved by the GC predict the future earnings surprises.

Our results suggest that restricted trading windows, by themselves, are not effective at reducing informed trading. Rather, the results suggest that the effectiveness of restricted trade windows depends on whether individual transactions require GC approval. Specifically, we find that trades inside restricted windows earn risk-adjusted returns of $0.06 \%$ per day, $0.04 \%$ more than trades outside windows, but that trades inside restricted windows approved by GC earn $0.01 \%$, a difference of $0.07 \%$ per day or $12.6 \%$ over the 180 days following the trade. This is in contrast to Bettis et al. (2000) who find that restricted trading windows are associated with decreased trading profits from 1992 to 1997. In additional analyses, we examine the Bettis et al. (2000) time period (and other time periods that precede recent regulatory changes), and effectively replicate their inferences that restricted trade windows are associated with lower insider trading profits. Importantly, this suggests that the primary tool used by firms to mitigate informed trade in prior periods is not especially effective in the current regulatory environment, which is perhaps an unintended consequence of recent regulations and what may be motivating an increased role of the GC in corporate governance. 
Several additional analyses support the inference that our findings are attributable to active governance by the $\mathrm{GC}$ rather than alternative explanations. One potential alternative explanation, for example, is that the GC approval requirement is found in firms that have lower ex ante information rents available to insiders (i.e. less information asymmetry that can be exploited by insiders). ${ }^{4}$ If this were true, it would not be surprising to observe less profitable trades at firms that require GC approval. However, we find that the GC approval requirement occurs more frequently in firms with greater information asymmetry (and therefore greater $e x$ ante information rents) and that $\mathrm{GC}$ approval is associated with a significant reduction in insider trading profits even when firms are matched based on measures of ex ante information rents. Additionally, we find firms that require GC approval of insider trades during our sample period do not have lower trading profits in prior periods, suggesting that the GC requirement itself, rather than some unobserved characteristic of the firm, is responsible for a decrease in trading profits. Overall, we interpret our findings as suggesting that the general counsel can effectively mitigate informed trade and that the choice of corporate governance directly affects the extent to which insiders use their private information to extract rents from shareholders.

Section 2 of this paper describes our sample selection and provides descriptive statistics for typical ITPs. Section 3 presents the trading profitability results across various roles for the general counsel. Section 4 discusses sensitivity analyses and concluding remarks are presented in Section 5.

\section{Sample and Descriptive Statistics for Insider Trading Policies}

\subsection{Sample}

\footnotetext{
${ }^{4}$ We refer to information rents available to the insiders absent any trading restrictions as "ex ante information rents".
} 
There is not a convenient source of insider trading policies (ITPs) for publicly traded firms because there is no formal requirement for firms to file ITPs with the SEC. Our initial step in developing a sample of ITPs was to electronically search (or "web crawl") public company websites for posted ITPs during the months of September 2006 through February 2007. We obtain all ticker symbols from CRSP, and use Google Finance to identify the main company website address. The website was then searched (using the advanced search options at Google) for the literal phrase "insider trading policy" and broader strings such as (insider OR executive) AND (trade OR trading OR trader OR trades). Since some firms contract their investor relations websites to third parties, we also scanned one third party investor relations website using various versions of the company name $(*)$ and restricting the domain to *.corporate-ir.net. Once a potential ITP was found by the search, the associated document was saved and manually read to determine whether it was an actual ITP. The electronic search produced 437 ITPs (Table 1, Panel A). Although there seems to be little proprietary information in the ITP and many companies have corporate governance material on their websites, ITPs are generally not publicly available for most firms.

In order to expand our sample, we also directly requested ITPs from companies in collaboration with the Society of Corporate Secretaries and Governance Professionals (denoted Society). Specifically, the Society sent an email to its membership asking for a copy of the ITP used at their company. This direct request is similar to the approach used by Bettis et al. (2000) and enables us to obtain ITPs that are not publicly disclosed for companies. This request produced ITPs for an 85 additional companies. The key portions of several ITPs are presented in Appendix A. 
The total of 522 unique ITPs was further reduced by data requirements (see Table 1, Panel A). Specifically, we require the firms to be listed in the U.S., covered by Compustat and Thomson Financial, have information in the ITP to compute the blackout window, have an earnings announcement in the time period twelve months after the adoption of Sarbanes-Oxley (or after June, 2003) on Compustat, and have at least one insider trading transaction in the time period from June, 2003, to December, 2005 on Thomson. ${ }^{5}$ We also require the firm to have an earnings announcement date within 3 months of the quarter-end. Since some trading polices define blackout windows in terms of the prior quarter's earnings announcement, we also collect but do not require the date of the earnings announcement for the prior quarter. When the prior quarter's announcement date is necessary to compute the blackout window but not available, the respective firm quarter is removed.

Our final sample consists of 260 firms that span a variety of industrial sectors (Table 1, Panel B). However, there is some concentration of the sample in the Fama and French (1997) manufacturing, business equipment, and finance industries. Specifically, these industries comprise about $51 \%$ of our sample relative to $48 \%$ of the COMPUSTAT population. Our firms are also somewhat larger, with a mean (median) market capitalization of $\$ 4,935(\$ 920)$ million (Table 1, Panel C).

\subsection{Descriptive Statistics for the Insider Trading Policies}

The primary data collected from each ITP consists of the length of the restricted trade window (prior to and after an announcement), and whether general counsel approval is required for any

\footnotetext{
${ }^{5}$ We use the time period starting in June, 2003, to allow firms sufficient time for updating and disclosing their ITP and to ensure that the resulting variables are measured under the new legal regime (i.e., six months after SEC Rule 10b5-1 and Sarbanes-Oxley). Brochet (2010) shows that Sarbanes-Oxley materially affects insider trading activity and profitability.
} 
insider trade. ${ }^{6}$ Appendix A provides several examples of ITPs and our coding of these documents (see also American Society of Corporate Secretaries, 2001).

The basic descriptive statistics for our sample of ITPs are presented in Table 2 (Panel A). GC approval is required to trade for $80 \%$ of firms. The mean (median) blackout window is approximately 46 (47) days prior to an announcement and one (one) day after an announcement. ${ }^{7}$ These results are generally comparable to those in Bettis et al. (2000) and the Society of Corporate Secretaries and Governance Professionals survey (2005).

Like Bettis et al. (2000), we do not know the precise adoption date for each ITP. Since we know the specific ITP in place as of September 2006, we assume that the ITPs in our sample also cover trades by executives during the time period from June 2003 to December 2005. Although not a rigorous validation, our conversations with general counsel and company officers indicates that the terms of ITPs are relatively stable over time. Insider transaction data for this time period was collected from Thomson Financial (Form 4 filings). For each transaction we require the trade price, the number of shares transacted, and the type of trade (buy, sell, gift, etc). Consistent with prior work, we restrict our analyses to non-compensation related equity purchases and sales of common stock under insiders' direct control. Finally, we aggregate insider trading data to the firm-day unit of analysis. The sample has 7,856 net daily transactions corresponding to fiscal quarters over the period June 2003 to December 2005.

Similar to prior research (e.g., Lakonishok and Lee, 2001), we observe that the typical insider trade is a sales transaction (Table 2, Panel B). Table 2, Panel B indicates that $24 \%$ of all

\footnotetext{
${ }^{6} \mathrm{We}$ also collect information on whether insiders are forbidden from holding securities in a margin account (80\% of the firms) and whether the restricted window applies to all employees, as opposed to only Section 16 officers, directors senior vice presidents, etc. (16\% of the firms).

${ }^{7}$ Although a variety of corporate events can trigger the opening of a window, the most frequent event (by far) is the issuance of the quarterly earnings release (see Society of Corporate Secretaries and Governance Professionals survey, 2005).
} 
insider trades during the sample period were executed within a restricted trading window. ${ }^{8}$ This is striking because it suggests a willingness of insiders (and some GCs) to permit trades contrary to company policy. ${ }^{9}$ This is consistent with either insider use of Rule 10b5-1 trade plans that can execute trades within firm-imposed restricted trade windows (Jagolinzer, 2009) or the insider trading behavior not being affected by restricted trade windows. In subsequent analyses we examine whether these trades are more or less informed than trades outside restricted trade windows.

\section{Information Content of Insider Trades}

Insider trades can reflect both private information and/or individual liquidity needs. As such, not all insider trades are necessarily informed. Therefore, the degree to which insider trades are informed needs to be estimated. Prior work uses two distinct methods to estimate the information content of insider traders. The first method involves computing insider trading profits, and testing whether insider trades consistently earn abnormal profits. In an efficient market, only trades based on private information earn profits. Thus, if insiders' trades consistently earn profits, it suggests such trades are based on private (non-public) information. The second method involves testing whether insider trades predict future value relevant information (e.g., earnings surprises). If insiders are trading on private information, it raises the question as to what the information pertains to. Although not the only plausible source of private information, future earnings surprises are a natural candidate for the information known to insiders (e.g., Piotroski

\footnotetext{
${ }^{8}$ Although strictly an exploratory observation, insiders at firms with non-public ITPs trade more often during the blackout window than insiders at firms that publicly disclose their ITP. We find no difference in average trade magnitude across these two groups.

${ }^{9}$ Of the 7,856 trades, $6,515(1,341)$ trades occurred at firms that did (did not) require GC approval. Of these 4,880 $(1,121)$ occurred outside restricted trade windows and 1,635 (220) occurred inside restricted trade windows.
} 
and Roulstone, 2005). If insiders are trading based on private information about future earnings, insider trades should predict the earnings surprise.

\subsection{Profitability of Insider Trades}

We calculate trading profits as follows. Every trading day, we net the transactions of all insiders at the firm. We measure trade profitability as the intercept (or alpha) from the four factor Fama-French (1993) and Carhart (1997) model estimated over the 180 days following each transaction: ${ }^{10}$

$$
\left(R_{i}-R_{f}\right)=\alpha+\beta_{1}\left(R_{m k t}-R_{f}\right)+\beta_{2} S M B+\beta_{3} H M L+\beta_{4} U M D+e,
$$

where $R_{i}$ is the daily return to firm $i$ 's equity, $R_{f}$ is the daily risk-free interest rate; $R_{m k t}$ is the CRSP value-weighted market return, $S M B, H M L$, and $U M D$ are the size, book-to-market, and momentum factors (Fama and French, 1993; Carhart, 1997), and $\alpha(-\alpha)$ is the average daily riskadjusted return to purchases (sales), i.e., TradingProfit. ${ }^{11}$ There are at least two advantages to this approach. First, estimating average daily abnormal returns allows us to avoid the biases inherent in statistical tests of long-run buy-and-hold returns (e.g. Kothari and Warner, 1997; Barber and Lyon, 1997; Mitchell and Stafford, 2000). Second, computing trade-day specific riskadjusted returns relative to the Fama-French model allows us to control for differences in risk across transactions (i.e. transaction-day specific factor loadings) and provides a trade-specific measure of profitability.

\footnotetext{
${ }^{10}$ Prior research generally computes abnormal returns over a six-month horizon, since insiders are penalized for profits earned on trades made fewer than 180 days subsequent to prior trades (i.e., "short-swing" rule: Section 16(b) of the Securities and Exchange Act of 1934).

${ }^{11}$ Results are robust to estimating equation (1) including one and two lags of all factors to correct for infrequent trading (e.g., Dimson, 1979). Results are also robust to measuring trading profits using six-month market-adjusted buy-and-hold returns.
} 
To assess the impact of insider trading restrictions on insider trading profitability, we partition TradingProfit by whether the trade occurs inside or outside a restricted trade window (InWin). We also further partition trade profitability based on whether the firm has a policy requiring trades to be approved by the general counsel $(G C) .{ }^{12}$ Specifically, we estimate the following regression:

$$
\text { TradingProfit }_{i, t}=\beta_{0}+\beta_{1} G C_{i}+\beta_{2} \operatorname{InWin}_{i, t}+\beta_{3} G C_{i} * \operatorname{InWin}_{i, t}+\varepsilon_{i, t}
$$

where $i$ denotes firm, $t$ denotes day, TradingProfit is the measure of insider trading profits estimated in equation (1), GC equals one if general counsel approval is required and zero otherwise, and InWin equals one if the trade occurs inside the firm's restricted trading window and zero otherwise.

The interaction term is interpreted as follows: $G C_{i} * \operatorname{In} W i n_{i, t}$ is 1 if the trade occurred within a restricted window and required GC approval. The coefficients on the indicator variables represent the difference in conditional means. For example the coefficient on $\operatorname{In}_{\mathrm{Win}} n_{i, t}$ is the difference in the average daily risk-adjusted return between trades within a restricted window and trades outside the restricted window (for firms that do not require GC approval). To correct for cross-sectional and time-series dependence we cluster standard errors by transaction date and firm (e.g., Gow et al., 2010), and to control for outliers we delete observations with studentized residuals greater then three (e.g., Belsley et al., 1980).

\subsection{Predictive ability of insider trades for earnings surprises}

In our next set of tests, we examine whether insider trades prior to the earnings announcement predict the earnings surprise. As a baseline, we first estimate the regression:

\footnotetext{
${ }^{12}$ Results are robust to further partitioning the sample based on whether the firm's ITP was publicly disclosed.
} 


$$
\text { Surprise }_{i, q}=\beta_{0}+\beta_{1} \text { NetTrade }_{i, q}+\beta_{2} \text { Size }_{i, q}+\beta_{3} B M_{i, q}+\varepsilon_{i, q}
$$

where $i$ denotes firm, $q$ denotes quarter, and Surprise $_{i, q}$ is either $\Delta E_{a r n}{ }_{i, q}$ or Anncret $t_{i, q}$. NetTrade $_{i, q}$ is the net insider trade (volume of buys less volume of sales, as a percent of shares outstanding) over the three months prior to the earnings announcement, $S i z e_{i, q}$ is the natural log of market value at the beginning of the quarter. $B M_{i, q}$ is book value (data \#59) scaled by market value at the beginning of the quarter. $\triangle E A R N_{i, q}$ is the forecast error from a seasonal random walk model of quarterly earnings (data \#8) scaled by total assets (data \#44) and in percent. Anncret is $_{\text {is }}$ the earnings announcement period return, measured as the three-day market-adjusted buy-andhold return centered on the earnings announcement date in percent. This regression estimation departs from the earlier profitability tests, in so far as the analysis is conducted at the firmquarter level rather than the trade level. Because earnings surprises are measured quarterly, aggregating insider trades to the quarterly level avoids repeat observations of the dependent variable and control variables. ${ }^{13}$

To assess the impact of insider trading restriction on the association between insiders' trades and operating performance we decompose NetTrade into two components, the portion occurring inside the restricted trade window and the portion occurring outside the restricted trade window. Specifically we estimate

$$
\begin{aligned}
& \text { Surprise }_{i, q}=\beta_{0}+\beta_{1} \text { WindowTrade }_{i, q}+\beta_{2} \text { NonWindowTrade }_{i, q} \\
& +\beta_{3} \text { GC }_{i}+\beta_{4} G C_{i} \text { WindowTrade }_{i, q}+\beta_{5} \text { GC }_{i}{ }^{*} \text { NonWindowTrade }_{i, q} \\
& +\beta_{6} \text { Size }_{i, q}+\beta_{7} B M_{i, q}+\varepsilon_{i, q}
\end{aligned}
$$

where WindowTrade is the net insider trade that occurs within the restricted trade window (volume of buys within the window less volume of sales within the window, as a percent of

\footnotetext{
${ }^{13}$ Results are quantitatively similar if we estimate equations (3) and (4) at the trade level rather than the firm-quarter level and if we separately consider purchases and sales.
} 
shares outstanding) and NonWindowTrade is the net insider trade that occurs outside the restricted trade window (volume of buys outside the window less volume of sales outside the window, as a percent of shares outstanding), and all other variables are as previously defined. Note that NetTrade is the sum of WindowTrade and NonWindowTrade. To correct for crosssectional and time-series dependence we cluster standard errors by quarter and firm, and to control for outliers we delete observations with studentized residuals greater then three.

\subsection{Results}

\subsubsection{ITP restrictiveness and insider trading profitability}

Table 3 presents results from estimating trade-specific risk-adjusted returns following insiders' transactions. Averaging across purchase and sales transactions, Table 3 shows that the average risk-adjusted return is not statistically different from zero ( $t$-stat. of -0.63$)$. Consistent with prior research (e.g., Seyhun, 1986; Lakonishok and Lee, 2001), Table 3 indicates that purchase transactions earn statistically positive risk-adjusted returns of $0.06 \%$ per day over the 180 days following the transaction ( $t$-stat. of 3.19). Also consistent with prior research (e.g., Lakonishok and Lee, 2001), sales transactions do not appear to earn significant returns ( $t$-stat. of $-1.57)$.

To better understand the implications of firm-imposed restrictions and particularly the role of GC oversight, Table 4 provides results regarding the estimation of equation (2), where governance elements of the insider trading policy are considered. Panel A, which pools purchase and sales transactions, reports that trades not subject to GC approval and executed outside restricted windows tend to earn positive returns (Model 3, Intercept $=0.02 \%, t$-stat. of 1.89). Panel A also reports that insiders' trades not subject to GC approval and executed inside 
restricted windows earn even greater returns (Model 3, InWin $=0.04 \%$, $t$-stat. of 2.34). This evidence is consistent with the timing of restricted trade windows being associated with periods of heightened information asymmetry. However, this evidence is inconsistent with Bettis et al. (2000) who find that insiders' trades are less (not more) profitable when executed inside restricted trade windows. This may indicate that changes in insider trading regulation (e.g., Rule 10b5-1, SOX) since the period studied by Bettis et al. (2000), 1992-1997, have altered the efficacy of restricted trade windows in reducing insiders' information rents.

To the extent the GC limits informed trade, we expect the effect of GC oversight on insider trades to be most pronounced when such trades have greater potential to be informed and therefore induce greater legal jeopardy (e.g., Huddart et al., 2007). Thus, if trades inside restricted trade windows are more likely to be informed because this is a period of heightened information asymmetry, we expect the effect of the GC to be most pronounced on trades executed inside restricted trade windows. Consistent with this, Panel A reports robust evidence that GC approval significantly reduces insiders' trading profits when trades are executed both inside and outside restricted trade windows, but that the effect is largest for trades inside restricted windows. Specifically, trades outside restricted trade windows that are approved by the GC earn $0.03 \%$ less per day than similar trades not approved by the GC (Model 3, GC $=-0.03 \%$, $t$-stat of. -2.33) and trades inside restricted trade windows that are approved by the GC earn 0.07\% less per day than similar trades not approved by the GC, a difference of $-0.04 \%$ (Model 3, $G C^{*} \operatorname{In}$ Win $=-0.04 \%, t$-stat. of -2.02$)$.

Panels B and C consider purchase and sales transactions separately. Further consistent with the GC primarily being motivated by concerns over the legal jeopardy of the trade, we find that the effect of the GC is concentrated among trades that (absent GC approval) have greater 
potential to be informed and therefore induce greater legal risk. Consistent with similar levels of informativeness and therefore similar levels of legal jeopardy, for purchases, we do not observe a difference in profits between trades executed inside $(0.09 \%$ per day over the 180 days following the trade) and outside ( $0.13 \%$ per day over the 180 days following the trade) restricted trade windows (Panel B, Model 3, Intercept $=0.09 \%, t$-stat of 2.66; InWin $=0.04 \%, t$-stat of 0.68 ). Moreover, consistent with the GC being motivated by legal jeopardy, and with similar legal jeopardy for purchases regardless of whether they are inside a restricted window, we find the GC is equally diligent in monitoring purchases inside and outside windows. Specifically, GC approved purchases outside the window earn $0.07 \%$ less per day (Panel B, Model 3, GC =$0.07 \%, t$-stat. of -2.08 ) and GC approved trades inside the window earn $0.08 \%$ less per day, a statistically insignificant difference $-0.01 \%\left(G C^{*} \operatorname{In} \operatorname{Win}=-0.01 \%, t\right.$-stat of -0.19$)$.

However, for sales, we find trades executed inside restricted trade windows are more profitable (and therefore more likely to be informed and litigated) than trades outside windows. Specifically, sales outside restricted trade windows earn $0.01 \%$ per day and sales inside restricted trade windows earn $0.05 \%$ per day $($ Panel C, Model 3, Intercept $=0.01 \%, t$-stat of $0.77 ;$ InWin $=$ $0.04 \%, t$-stat of 2.81). Consistent with the GC being motivated by legal jeopardy, and with greater legal jeopardy for sales inside restricted windows, we find the effect of the GC is greatest for sales inside restricted windows. Specifically, we find GC approved sales outside the window earn $0.02 \%$ less per day (Panel B, Model 3, GC $=-0.02 \%, t$-stat. of -0.14 ) and GC approved trades inside the window earn $0.07 \%$ less per day, a statistically significant difference of $0.05 \%$ (Panel B, Model 3, GC*InWin $=-0.05 \%, t$-stat of -2.36 ).

Collectively, the evidence from Table 4 suggests that GC approval is associated with a substantial reduction in insider trading profits. Thus, when given the authority, it appears the GC 
can effectively limit the extent to which insiders use their private information to extract rents from shareholders.

\subsubsection{ITP restrictiveness and earnings surprises}

Table 5 presents results regarding the association between restrictions in the ITP and the ability of insider trades to predict earnings surprises. Earnings surprise is measured using two variables, the forecast error from a seasonal random walk model of earnings (LEarn) and the short window investor response to the earnings announcement (Anncret). The first variable captures fundamental operating performance of the firm and the latter measure captures whether this performance met investors' expectations for the period.

Table 5 suggests three important inferences. First, on average insider trades in our sample do not predict earnings surprises measured using realized earnings or earnings announcement period returns (Model 1, NetTrade t-stat. of 1.04 and 0.77 respectively). Second, after decomposing insider trades over the quarter into those trades executed inside and outside restricted trade windows, and those trades approved and not approved by the GC (i.e., Model 2), we find that trades outside restricted trade windows not approved by the GC predict earnings surprises measured using realized earnings (NonWindowTrade, $t$-stat. of 3.00) and that trades inside and outside restricted trade windows not approved by the GC predict earnings announcement period returns (WindowTrade, $t$-stat. of 9.37 and NonWindowTrade, $t$-stat. of 2.45). Third, and in contrast, trades approved by the general counsel have significantly lower predictive ability for surprises measured using realized earnings (GC*NonWindowTrade, $t$-stat. of -2.89$)$ and earnings announcement period returns (GC*WindowTrade, $t$-stat. of -3.49 and $G C^{*}$ Non WindowTrade, $t$ stat of -2.48). In fact, trades outside restricted trade windows that are approved by the GC have 
no predictive ability for surprises measured using realized earnings ( $p$-value of 0.27 for F-test GC*NonWindowTrade + NonWindowTrade $=0$ ). Similarly, trades approved by the general counsel have no predictive ability for future earnings announcement period returns ( $p$-values of 0.68 and 0.28 for F-tests $G C^{*}$ NonWindowTrade + NonWindowTrade $=0$ and $G C^{*}$ WindowTrade + WindowTrade $=0$, respectively).

The results presented in Table 5 support the inference that insiders' trades tend to be privately informed, but less so when general counsel approval is required. These results provide confirmatory evidence that cross-sectional variation in insider trading profits is likely due to cross-sectional variation in the use of private information. ${ }^{14}$

\section{Additional Analyses}

\subsection{Alternative explanations}

Rather than the GC actively limiting insider's ability to extract information rents, an alternative explanation for our results is that GC approval is required only at firms that have lower ex ante information rents available to insiders (e.g., less information asymmetry that can be exploited by insiders). This situation might occur, for example, if insiders have control over the governance of the firm and implement a GC approval requirement only when it is not personally costly, in terms of foregone rents. We rely on three techniques to test this alternative explanation.

First, this explanation predicts that GC approval is required in firms where ex ante information rents (i.e., profitable insider trading opportunities absent restrictions) are low. Accordingly, we examine the characteristics of firms that require GC approval of insider trades,

\footnotetext{
${ }^{14}$ The association between insiders' trades and earnings surprises make it less likely that reported returns associations (Table 4) result from investors' response to insiders' trade disclosures.
} 
and whether this requirement is concentrated in firms that would appear to have limited information rents otherwise available to insiders.

Second, this explanation predicts that, holding constant the level of ex ante information rents, GC approval is not associated with a reduction in trading profits. Accordingly, we match firms that require GC approval to firms that do not require GC approval based on several proxies for the level of ex ante information rents available to insiders (e.g., measures of governance and information asymmetry). We then test whether GC approval is associated with decreased trading profits even among firms with similar levels of ex ante information rents.

Finally, this explanation predicts that firms that require GC approval have historically lower trading profits than firms that do not require GC approval. Accordingly, we examine whether firms that require GC approval during our sample period, post-SOX, have lower trading profits in prior periods, pre-SOX. If firms that require GC approval post-SOX also have lower trading profits pre-SOX, it suggests that active monitoring by the GC is not the cause of the reduced profits, but rather that such firms simply have fewer opportunities for profitable insider trading.

\subsubsection{Firm characteristics associated with GC approval}

To examine whether GC approval is more common in firms that have lower ex ante information rents, we estimate the probability that the firm requires GC approval of insider trades as a function of several governance and informational asymmetry variables thought to determine the level of rents available to insiders. In particular, we estimate the following logistic regression:

$\operatorname{Pr}(G C=1)=\frac{1}{1+e^{-\beta X}}$,

where, 


$\begin{array}{llllllll}\beta X= & \alpha_{0} & + & \alpha_{1} & \text { InsChair } & +\alpha_{2} & \text { LeadOutsDir } & + \\ \alpha_{3} & \text { InsidDirs\% } & + & \alpha_{4} & \text { AffilDirs } \% & +\alpha_{5} & \text { Restatements } & + \\ \alpha_{6} & \text { Blockholders } & + & \alpha_{7} & \text { Analysts } & +\alpha_{8} & \text { EarnVol } & + \\ \alpha_{9} & \text { IdioVol } & + & a_{10} & \text { Size } & +a_{11} & \text { BM } & +\varepsilon(6)\end{array}$

We measure corporate governance with six commonly used variables. InsChair equals one if the board chairman is an officer during both 2004 and 2005, equals 0.5 if the board chairman is an officer during one but not both of years 2004 and 2005, and equals zero otherwise.

LeadOutsDir equals one if the firm had a lead outside director during both 2004 and 2005, equals 0.5 if a lead outside director is observed during one but not both of years 2004 and 2005, and equals zero otherwise. InsidDirs $\%$ is the ratio of officer-directors to total directors, averaged across 2004 and 2005. AffilDirs\% is the ratio of affiliated directors (i.e., with a significant business relation to the firm) to total directors, averaged across 2004 and $2005 .{ }^{15}$ Restatements is the percent of years between 2001 and 2005 during which the firm made an accounting restatement. ${ }^{16}$ Blockholders is the natural log of one plus the number of CDA/Spectrum-denoted 5\% institutional blockholders, averaged across 2004 and 2005.

We measure the degree of information asymmetry between managers and shareholders using three variables. Analysts is the natural log of one plus the number of analysts providing estimates of one-year-ahead earnings forecasts on I/B/E/S, averaged across 2004 and 2005. EarnVol is the standard deviation of the ratio of annual net income to beginning assets, for years 1996 through 2005. IdioVol is the standard deviation of daily returns in excess of the CRSP value-weighted market portfolio, for years 2004 and $2005 .{ }^{17}$ Because prior research shows that firm size and

\footnotetext{
${ }^{15}$ InsChair, LeadOutsDir, InsidDirs\%, AffilDirs\%, are obtained from proxy statement data provided by Equilar Inc.

${ }^{16}$ These data were obtained from the comprehensive sample of restatements collected by Glass-Lewis Inc.

${ }^{17}$ Results are also robust to including the following additional measures of information asymmetry: average daily share turnover, average daily bid-ask spread, an indicator variable for whether R\&D expense is positive, and the
} 
valuation affect the level of insider trading (e.g., Seyhun, 1986; Rozeff and Zaman, 1998), we also include Size, which is the natural log of market value measured quarterly and averaged over the sample period, and $B M$, which is the ratio of book value of equity to market value of equity measured quarterly and averaged over the period.

Table 6, Panel A presents regression results. Evidence indicates that there is a lower likelihood of observing a GC approval requirement at firms with a greater historical frequency of accounting restatements (Restatements, $t$-stat. of -2.36 ). This result seems intuitive if accounting restatements are more likely at firms with less attentive governance. Evidence also indicates that the likelihood of observing a GC approval requirement is decreasing in analyst coverage (Analysts, $t$-stat. of -2.53 ). This result suggests that firms with less information asymmetry between managers and shareholders (i.e. greater analyst coverage), where insiders stand to gain less from trading, are less likely to require GC approval. This is inconsistent with the notion that insiders control the governance of the firm and put a GC approval requirement in place only when they have little to gain from trading. Instead, the results are consistent with GC oversight being less likely at firms with low information asymmetry because there are lower ex ante information rents available to insiders from trading.

\subsubsection{Propensity score matching}

To help assess the alternative explanation that GC approval is associated with decreased trading profits because there are less ex ante information rents available at firms that require GC approval, we match firms that require GC approval to firms that do not require $\mathrm{GC}$ approval based on proxies for the level of ex ante information rents. Matching allows us to control for 
factors that affect the level of ex ante information rents available at the firm, without relying on parametric assumptions about the relationship between observable firm characteristics and the level of rents (see Armstrong et al., 2010 and Larcker and Rusticus 2010, for a discussion). ${ }^{18}$

We construct our matched sample using propensity scores where the treatment variable is whether GC approval is required for insider trades. We identify matched pairs by selecting an observation that received the treatment (GC approval requirement) and selecting another observation with the closest propensity score that did not receive the treatment. We calculate our propensity score by estimating the probability that the firm requires the GC to approve insider trades as a function of several governance and informational asymmetry variables thought to determine the level of rents available to insiders (see equation (5)) and form 104 match pairs that differ depending on whether GC approval is required for insider trades. ${ }^{19}$

An important step in forming a matched sample is to evaluate covariate balance. Covariate balance ensures that the treatment and matched control sample are similar across all dimensions except the variable of interest, i.e., the GC approval requirement. We assess covariate balance between the treatment and control groups using a $t$-test of the difference in means, a Wilcoxon $z$ test for difference in medians, and a Kolmogrov-Smirnov $(K S)$ test of the difference in distributions. The results in Table 6 (Panel B) suggest that the propensity score matched control sample resembles the treatment sample along all relevant observable dimensions.

Estimates of the treatment effect related to GC approval are presented in Table 6 (Panel C). We find strong evidence that insider trades that require GC approval earn substantially lower

\footnotetext{
${ }^{18}$ Results are robust to using two-stage probit-least-squares as an alternative, where equation (5) is the first stage. Results are also robust to including the governance and information asymmetry variables from equation (6) directly in equations (2) and (4). We find no evidence of a relation between these governance variables and trading profits. ${ }^{19}$ In our sample of 260 firms, fifty two (20\%) do not require GC approval. These fifty two are then matched to fifty two firms that require GC approval with the closest propensity score. This reduction in sample size decreases the power of our tests.
} 
profits than trades that do not require GC approval. Specifically, the average risk-adjusted return of trades without GC approval is $0.03 \%$ per day compared to $0.01 \%$ for trades with GC approval, a difference of $0.02 \%$ or $3.60 \%$ over the 180 days following the trade (TradingProfit, $t$-stat. of 2.05). Results are similar if we focus on trades inside a restricted window. The average riskadjusted return for trades executed inside restricted windows and without $\mathrm{GC}$ approval is $0.07 \%$, compared to $0.03 \%$ for trades executed insider restricted windows but with GC approval, a difference of $0.04 \%$ or $7.20 \%$ over the 180 days following the trade (TradingProfit, $t$-stat. of 1.98). These results suggest that GC approval is associated with a reduction in insider information rents even among firms with similar levels of information rents available. ${ }^{20}$

\subsubsection{Historical trading profits}

To examine whether insiders at firms that require GC approval during our sample period have historically lower trading profits available to insiders, we test whether firms that require GC approval in our sample period, post-SOX, also have lower trading profits in prior periods that predate recent regulatory events that alter the enforcement environment (Rule 10b5-1 and the Sarbanes-Oxley Act). Specifically, we examine the effect of restricted trade windows and GC approval on insider trading profits for the time period 1992 to 1997 (e.g., Bettis et al., 2000) and an expanded period from 1992 to 2002 (e.g., Huddart et al., 2007, the start of SOX). ${ }^{21}$

\footnotetext{
${ }^{20} \mathrm{We}$ assess the sensitivity of our results to omitted variables using a bounding technique developed by Rosenbaum (2002) for application to propensity score matched samples (see Armstrong, Jagolinzer, and Larcker (2010) for more details). We find that for the effect of the GC on insider trading profits to be reduced to marginally significant (i.e., $p$-value of 0.10 , two-tail), the omitted variable must result in firms being twice as likely (rather than equally likely) to have GC approval after controlling for corporate governance, information asymmetry, firm size, and book-tomarket. While not impossible, we believe that it is unlikely that there is an omitted variable with this high level of correlation driving our results.

${ }^{21}$ While not using data on actual restricted trade windows, Huddart et al. (2007) compares the profitability of trades made shortly before earnings announcements to those at other times from 1996-2002. Huddart et al. (2007) find the frequency of net purchases over the 20 days before the earnings announcement is positively associated with earnings
} 
Consistent with Bettis et al. (2000), we find that trades executed within a restricted trade window in these earlier periods are, on average, less profitable than trades executed outside a restricted trade window. In particular, from 1992 to 2002, we find that trades inside (outside) restricted windows earn risk-adjusted returns of $-0.04 \%(0.01 \%)$ per day, a difference of $0.05 \%$ ( $t$-stat. of $1.99) .^{22}$

Additionally, we do not observe any evidence of decreased trading profits during these earlier periods for firms that subsequently require GC approval during our sample period (20032005). In particular, from 1992 to 2002, we find that trades at firms that do (do not) subsequently require GC approval earn $-0.01 \%(0.01 \%)$ per day, a difference of $0.02 \%$ ( $t$-stat. of 0.87). This is inconsistent with the alternative explanation that firms which require GC approval have lower ex ante information rents available to insiders. Instead, the results suggest the GC requirement itself, rather than some unobserved characteristic of the firm, is responsible for a decrease in trading profits in our sample time period.

\subsection{Efficacy of alternative measures of trade inside restricted windows}

Without the advantage of data regarding the actual timing of restricted trade windows, it is difficult to infer whether a given trade occurs inside or outside a restricted window. Nonetheless, absent such data, prior work infers that trades in the period beginning one month after the previous earnings announcement and ending on the day of the current quarter's earnings announcement occur inside a restricted trade window (e.g., Roulstone, 2003). While the advantage of such a rule is that it can be applied to a large number of firms without requiring data on actual restricted trade windows, the disadvantage is that it is relatively imprecise. For

announcement period returns, but no association for the dollar value of net purchases or non-directional measures of trade.

${ }^{22}$ For parsimony we discuss but do not tabulate these results from re-estimating equation (2) for the earlier period. The coefficient on InWin is -0.05 ( $t$-stat. of 1.99), all other coefficients are insignificant. 
example, the average firm in our sample has a restricted window 48 days long that ends one day after the earnings announcement. Therefore, it is unclear to what degree this rule misclassifies trades as inside or outside restricted trade windows.

Using data on the actual dates of restricted trade windows for firms in our sample, we compare inferences under both the actual window and the "inferred window" based on Roulstone (2003). We find that the "inferred window" correctly classifies $81.13 \%$ (90.02\%) of trades occurring inside (outside) the window. For comparison, an alternative rule is to naively apply the average restricted window length before and after the earnings announcement to all firms. This rule (46 days before, 1 day after) correctly classifies $83.21 \%(89.27 \%)$ of trades occurring inside (outside) the window. Repeating our analyses using either inferred window measure does not alter inferences about the effect of the GC. However, it does alter inferences about the effect of restricted windows on insider trading profits. Specifically, using both inferred window measures, we no longer find that restricted windows are associated with trading profits, positively or negatively. Thus, the use of inferred windows appears to introduce significant measurement error and therefore researchers should exercise caution when interpreting null results based on inferred windows.

\section{Summary and Conclusions}

This paper examines the impact of the firm's internal control process, specifically actions taken by the general counsel - on the ability of insiders to use their private information to extract rents from shareholders. If informed trading by insiders is considered undesirable by shareholders or illegal by regulators, corporate governance should manifest itself in restrictive 
governance elements within the firm's insider trade policy. Using a unique sample of detailed insider trading policies, we find that active monitoring by the general counsel is associated with a substantial reduction in inside trading profits and the ability of insider trades to predict earnings surprises. In contrast to prior literature, we find that restricted trade windows do not appear binding and that insider trades made within these windows (absent general counsel approval) are generally informed. Collectively, our results, suggest that the general counsel is an active component of an overall governance structure and that the choice of corporate governance directly affects the extent to which insiders use their private information to extract rents from shareholders. 


\section{References}

Aboody, D., and B. Lev. 2000. Information Asymmetry, R\&D and Insider Gains. Journal of Finance 55, p. 2747-2766.

American Society of Corporate Secretaries. 2001. Insider trading policies: A representative sampling (New York, NY. American Society of Corporate Secretaries).

Armstrong, C., Jagolinzer, A., and D. Larcker. 2010. Chief executive officer equity incentives and accounting irregularities. Journal of Accounting Research 48, p. 225-271.

Barber, B. M., and J. D. Lyon. 1997. Detecting long-run abnormal stock returns: The empirical power and specification of test statistics. Journal of Financial Economics 43, p.341-372.

Batson, N. 2003. Second interim report of Neal Batson, Court Appointed Examiner, In Re: Enron Corp. et al., Debtors. United States Bankruptcy Court, Southern District of New York, Case No 01-16034.

Belsley, D. A., E. Kuh, and R. E. Welsch. 1980. Regression Diagnostics. New York, NY: Wiley.

Bettis, J., J. Coles, and M. Lemmon. 2000. Corporate policies restricting trading by insiders. Journal of Financial Economics 57, p. 191-220.

Bhagat, S., and B. S. Black. 1998. Independent Directors. The New Palgrave Dictionary of Economics and the Law 2, p. 283-287.

Brochet, F. 2010. Information content of insider trades before and after the Sarbanes-Oxley Act. The Accounting Review 85, p. 419-446.

Carhart, M. M. 1997. On Persistence in mutual fund performance. Journal of Finance 52, p. 5782.

Core, J., Guay, W., and T. O. Rusticus. 2006. Does Weak Governance Cause Weak Stock Returns? An Examination of Firm Operating Performance and Investors' Expectations. Journal of Finance 61, p. 655-687.

Demott, D. 2005. The discrete roles of general counsel. Fordham Law Review 74, p. 955-981.

Dimson, E. 1979. Risk measurement when shares are subject to infrequent trading. Journal of Financial Economics 7, p. 197-226.

Fama, E. and K. French. 1993. Common risk factors in the returns on stocks and bonds. Journal of Financial Economics 33, p. 3-56.

Fama, E. and K. French. 1997. Industry costs of equity. Journal of Financial Economics 43, p. 153-193. 
Fich, E. M., and A. Shivdasani. 2006. Are Busy Boards Effective Monitors? Journal of Finance 61, p. 689-723.

Gompers, P., J. Ishii, and A. Metrick. 2003. Corporate governance and equity prices, Quarterly Journal of Economics 118, p. 107-155.

Gow, I., G. Ormazabal, and D. Taylor. 2010. Correcting for cross-sectional and time-series dependence in accounting research. The Accounting Review 85, p. 483-512.

Holmstrom, B. and S. Kaplan, 2003. The state of U.S. corporate governance: What's right and what's wrong? Journal of Applied Corporate Finance 15, p. 8-20.

Huddart, S. and B. Ke. 2005. Information asymmetry and cross-sectional determinants of in insider trading. Contemporary Accounting Research 24, p. 195-232.

Huddart, S., B. Ke, and C. Shi. 2007. Jeopardy, non-public information, and insider trading around SEC 10-K and 10-Q filings. Journal of Accounting \& Economics 43, p. 3-36.

Jagolinzer, A. D., 2009. SEC Rule 10b5-1 and insiders' strategic trade. Management Science, 55 , p. 224-239.

Ke, B. Huddart, S. J., and K. R. Petroni, 2003. What Insiders Know About Future Earnings and How They Use it: Evidence from Insider Trades, Journal of Accounting \& Economics 35, p. 315-346.

Kothari, S. P., and J. B. Warner. 1997. Measuring long-horizon security performance. Journal of Financial Economics 43, p. 301-339.

Lakonishok, J. and I. Lee, 2001. Are insider trades informative? Review of Financial Studies 14, p. 79-111.

Larcker, D. S. Richardson, and I. Tuna. 2007. Corporate governance, accounting outcomes, and organizational performance. Accounting Review 82, p. 963-1008.

Larcker, D. and T. Rusticus. 2010. On the use of instrumental variables in accounting research. Journal of Accounting and Economics 49, p. 186-205.

Mitchell, M. L., and E. Stafford, 2000. Managerial decisions and long-term stock price Performance. Journal of Business 73, p. 287- 329.

Piotroski, J. D., and D. Roulstone. 2005. Do Insider Trades Reflect Both Contrarian Beliefs and Superior Knowledge about Future Cash-Flow Realizations? Journal of Accounting and Economics 39, p. 55-82. 
Ravina, E., and P. Sapienza. 2010. What do independent directors know? Evidence from their trading. Review of Financial Studies 23, p. 962-1003.

Rosenbaum, P. R. Observational Studies, 2nd ed. Berlin: Springer Series in Statistics, 2002.

Roulstone, D. T. 2003. The relation between insider-trading restrictions and executive Compensation. Journal of Accounting Research 41, p. 525-551.

Rozeff, M., and M. Zaman. 1998. Overreaction and insider trading: Evidence from growth and value portfolios. Journal of Finance 53, p 701-716.

Seyhun H. N. 1986. Insiders' Profits, Costs of Trading, and Market Efficiency. Journal of Financial Economics 16, p. 189-212.

Society of Corporate Secretaries and Governance Professionals. 2005. Window period/blackout period trading practices survey (New York, NY. Society of Corporate Secretaries and Governance Professionals).

Winders, P. 2005. Law Firm General Counsel Extravagance of Necessity, Professional Lawyer 15 , p. 3-11. 


\section{Appendix A. Examples of Insider Trading Policies}

Boeing: (coded as: $G C=1)$

They (company officers and certain other designated employees) are urged to trade in Boeing stock only during the period beginning on the third business day following the date of release of a quarterly or annual statement of sales and earnings and ending on the twelfth business day following such date.

Executive officers of the company ... are not permitted to trade in Boeing stock unless they have approval for a specific trade from the corporate secretary.

Maxwell Technologies: (coded as: $G C=0)$

... the Company requires that you trade in securities of the Company only during a period that (i) begins on the second trading day after a periodic earnings press release, and (ii) ends ten (10) business days before the end of the fiscal quarter during which such release was made. If you have any questions or are in doubt as to the propriety of any proposed trade or the significance of any information you may possess, the Company requests that you speak with the Company's Chief Financial Officer, in person, prior to making the trade in the Company's securities. 
RadioShack: (coded as: $G C=1$ )

... members of the board of directors, officers, senior directors, and region directors of RadioShack may buy or sell RadioShack securities only during the period beginning two full trading days after the release of RadioShack quarterly earnings and ending one calendar month prior to the end of the next fiscal quarter, as described in the table below:

\begin{tabular}{|l|l|}
\hline \multicolumn{1}{|c|}{ Trading Window Opens } & Trading Window Closes \\
\hline $\begin{array}{l}\text { Two full trading days after the annual earnings release (typically in } \\
\text { mid-February) }\end{array}$ & February 28/29 \\
\hline $\begin{array}{l}\text { Two full trading days after the 1Q earnings release (typically in mid- } \\
\text { April) }\end{array}$ & May 31 \\
\hline $\begin{array}{l}\text { Two full trading days after the 2Q earnings release (typically in mid- } \\
\text { July) }\end{array}$ & August 31 \\
\hline $\begin{array}{l}\text { Two full trading days after the 3Q earnings release (typically in mid- } \\
\text { October) }\end{array}$ & November 30 \\
\hline
\end{tabular}

The General Counsel may also require persons in addition to those listed above to comply with the trading window for specified time periods.

Notwithstanding the fact that a trading window is open,

- all members of RadioShack's board of directors and RadioShack's General Counsel (and their Related Persons) must obtain prior clearance from the Presiding Director of the board of directors, and

- all RadioShack officers (and their Related Persons) must obtain prior clearance from RadioShack's General Counsel

before placing any order for or making any purchase or sale of RadioShack securities, including any exercise of stock options. Prior clearance is required for all purchases or sales, including modifying investment options in RadioShack's 401(k) plan.

Notation: $\boldsymbol{G C}$ equals one if $\mathrm{GC}$ approval is needed to execute the trade and equals zero otherwise. 


\section{Table 1. Sample Compilation Statistics}

Panel A. Insider Trading Policy Sample

\begin{tabular}{|c|c|c|c|}
\hline & Web Crawl & Survey & Total \\
\hline Identified insider trading policies & 437 & 85 & 522 \\
\hline $\begin{array}{l}\text { Less: Firms not appearing in COMPUSTAT and not } \\
\text { incorporated in the US }\end{array}$ & -191 & 0 & -191 \\
\hline $\begin{array}{l}\text { Less: Firms with insufficient information to compute } \\
\text { blackout window dates (e.g. missing lag announcement date) }\end{array}$ & -34 & -6 & -40 \\
\hline Less: Firms not appearing in Thomson Insider & -15 & -4 & -19 \\
\hline $\begin{array}{l}\text { Less: Firms with no insider transactions over the sample } \\
\text { period }\end{array}$ & $\frac{-12}{185}$ & $\frac{0}{75}$ & $\frac{-12}{260}$ \\
\hline Total & 185 & 75 & 260 \\
\hline
\end{tabular}

\section{Panel B. Industry Classification}

\begin{tabular}{lrr}
\hline \hline & \% of Sample & \% of Compustat \\
& $(n=260)$ & $(n=18,629)$ \\
\cline { 2 - 3 } 1. Consumer Non-Durables & 4.62 & 4.58 \\
2. Consumer Durables & 1.92 & 2.13 \\
3. Manufacturing & 13.08 & 8.28 \\
4. Energy & 5.38 & 3.87 \\
5. Chemicals and Allied Products & 3.08 & 1.79 \\
6. Business Equipment & 15.77 & 18.10 \\
7. Telephone and Television Transmission & 1.54 & 4.13 \\
8. Utilities & 5.00 & 2.42 \\
9. Wholesale, Retail, Laundries, Repair Shops & 9.61 & 8.84 \\
10. Healthcare, Medical Equipment, and Drugs & 9.61 & 8.63 \\
11. Finance & 21.54 & 22.85 \\
12. Other & 8.85 & 14.39 \\
\hline
\end{tabular}

Panel C. Firm Characteristics

\begin{tabular}{lrrrrrrr}
\hline & \multicolumn{3}{c}{ Sample } & & \multicolumn{3}{c}{ Compustat } \\
& Mean & Median & Std & & Mean & Median & Std \\
\cline { 2 - 4 } \cline { 5 - 7 } MVE (\$ million) & 4935.13 & 920.70 & 21002.38 & & 2681.67 & 192.54 & 12562.93 \\
Assets (\$ million) & 10785.86 & 907.99 & 70322.23 & & 7078.66 & 244.95 & 57875.92 \\
BVE (\$ million) & 1934.82 & 355.36 & 6911.53 & & 1115.93 & 86.49 & 5253.96 \\
\hline \hline
\end{tabular}

Panel A reports the sample selection criteria. Web Crawl refers to policies obtained through a systematic web search conducted between September 2006 and February 2007. Specifically, all ticker symbols are obtained from CRSP and are then matched through Google Finance to identify the main company website address. Firm websites are searched (using the advanced search options at Google) for the literal phrase "insider trading policy" and broader strings such as (insider OR insider) AND (trade OR trading OR trader OR trades) AND (policy OR policies). One third party investor relations website is also searched using various versions of the company name $(*)$ and restricting the domain to *.corporate-ir.net. Once a potential ITP is found by the search, the associated document is saved and is manually read to determine whether this is an actual ITP. Survey refers to policies collected by surveying the members of the Society of Corporate Secretaries and Governance Professionals (denoted Society). Specifically, the Society solicited copies of firm-specific ITPs in December 2006. If ITPs were identified by both methods, the 
default classification is Web Crawl. Firms with ITPs must be listed in the U.S., be covered by Compustat and Thomson Financial, have information in the ITP to compute the blackout window, release an earnings announcement between June 2003 and December 2005, and have at least one insider trade over the same period. Firms with ITPs must also have an earnings announcement date within 3 months of the quarter end, and the date of the prior quarter earnings announcement if the policy defines trading blackout windows in terms of the prior quarter's earnings announcement date. Panel B reports the industry distribution of sample observations, classified by Fama and French (1997) industry groups. The industry distribution across all Compustat firms (with nonmissing SIC code data between 2003 and 2005) is provided for comparison. Panel C reports firm-size statistics for sample observations. $M V E$ is the average market value of equity (Compustat data14* data61), measured quarterly between June 2003 and December 2005. Assets is the average total assets (Compustat data44), measured quarterly between June 2003 and December 2005. BVE is the average book value of equity (Compustat data59), measured quarterly between June 2003 and December 2005. Firm-size statistics across all Compustat firms (with non-missing data between 2003 and 2005) are provided for comparison. 
Table 2. Policy-Related Statistics

Panel A. Insider Trading Policy Characteristics (N=260 firms)

\begin{tabular}{lrrrrr}
\hline & & & \multicolumn{3}{c}{ Percentile $^{\text {th }}$} \\
GC & 0.80 & Std. Dev & $25^{\text {th }}$ & \multicolumn{1}{c}{$50^{\text {th }}$} & \multicolumn{1}{c}{$75^{\text {th }}$} \\
\cline { 2 - 6 } WinLength & 0.40 & 1.00 & 1.00 & 1.00 \\
WinLength & 47.61 & 17.64 & 37.32 & 49.18 & 58.60 \\
WinLength $_{\text {post }}$ & 45.81 & 17.55 & 35.88 & 47.21 & 56.95 \\
\hline
\end{tabular}

Panel B. Insider Trading Variables ( $\mathrm{N}=7,856$ trades $)$

\begin{tabular}{lrrrrr}
\hline \hline & & & \multicolumn{3}{c}{ Percentile } \\
NetPurchRatio & Mean & Std. Dev & \multicolumn{1}{c}{$25^{\text {th }}$} & \multicolumn{1}{c}{$50^{\text {th }}$} & \multicolumn{1}{c}{$75^{\text {th }}$} \\
\cline { 2 - 6 } TradingProfit & -0.72 & 0.69 & -1.00 & -1.00 & -1.00 \\
InWin & -0.01 & 0.22 & -0.09 & 0.00 & 0.09 \\
GC*InWin & 0.24 & 0.42 & 0.00 & 0.00 & 0.00 \\
\hline \hline
\end{tabular}

Panel C. Governance and Information Rent Variables ( $\mathrm{N}=\mathbf{2 6 0}$ firms)

\begin{tabular}{lccccc}
\hline & & & \multicolumn{3}{c}{ Percentile } \\
& Mean & Std. Dev & $25^{\text {th }}$ & $50^{\text {th }}$ & $75^{\text {th }}$ \\
\cline { 2 - 6 } Governance Variables & & & & & \\
InsChair & 0.69 & 0.43 & 0.00 & 1.00 & 1.00 \\
LeadOutsDir & 0.43 & 0.46 & 0.00 & 0.00 & 1.00 \\
InsidDirs\% & 0.18 & 0.10 & 0.11 & 0.15 & 0.22 \\
AffilDirs\% & 0.14 & 0.13 & 0.00 & 0.11 & 0.21 \\
Restatements & 0.05 & 0.10 & 0.00 & 0.00 & 0.00 \\
Blockholders & 1.00 & 0.48 & 0.69 & 1.00 & 1.39 \\
& & & & & \\
Information Asymmetry Variables & & & & & \\
Analysts & 1.70 & 0.94 & 0.98 & 1.72 & 2.45 \\
EarnsVol & 0.18 & 0.41 & 0.02 & 0.06 & 0.14 \\
RetVol & 0.02 & 0.02 & 0.01 & 0.02 & 0.03 \\
\hline \hline
\end{tabular}

Insider trading policy, insider trade, and firm descriptive statistics are reported in Panels A, B, and C, respectively. $G C$ equals one if GC approval is needed to execute the trade and equals zero otherwise. WinLength is the length in calendar days of the restricted trade window. pre denotes the period prior to an earnings announcement. post denotes the period subsequent to an earnings announcement. NetPurchRatio is computed as the firm's daily insider net purchases scaled by insider volume. TradingProfit is the average risk-adjusted return for each transaction (in percent) calculated over the 180-days following the transaction and relative to the Fama and French (1993) and Carhart (1997) four factor models. InWin equals one if the observed transaction executes within a firm-imposed restricted window and equals zero otherwise. Ins Chair equals one if Equilar denotes the board chairman as a firm officer during both 2004 and 2005, equals 0.5 if the board chairman is denoted a firm officer during one but not both of years 2004 and 2005, and equals zero otherwise. LeadOutsDir equals one if Equilar denotes a lead outside director during both 2004 and 2005, equals 0.5 if a lead outside director is denoted during one but not both of years 2004 and 2005, and equals zero otherwise. InsidDirs\% is the ratio of Equilar-denoted officer-directors to total 
directors, averaged across 2004 and 2005. AffilDirs\% is the ratio of Equilar-denoted affiliated-directors to total directors, averaged across 2004 and 2005. Restatements is the percent of years between 2001 and 2005 during which Glass-Lewis denotes the firm made an accounting restatement. Blockholders is the log of one plus the number of CDA/Spectrum-denoted 5\% institutional blockholders, averaged across 2004 and 2005. Analysts is the $\log$ of one plus the number of analysts providing estimates of one-year-ahead earnings forecasts on $\mathrm{I} / \mathrm{B} / \mathrm{E} / \mathrm{S}$,

averaged across 2004 and 2005. EarnsVol is the standard deviation of the ratio of annual net income to beginning assets, for years 1996 through 2005. IdioVol is the standard deviation of daily returns in excess of the CRSP valueweighted market portfolio, for years 2004 and 2005. 
Table 3. Insider Trading Profits

\begin{tabular}{|c|c|c|c|}
\hline & All Trades & Purchase Trades & Sales Trades \\
\hline TradingProfit $t_{i, t}$ & $\begin{array}{l}-0.01 \\
(-0.63)\end{array}$ & $\begin{array}{l}\text { 0.06**** } \\
(3.19)\end{array}$ & $\begin{array}{l}-0.02 \\
(-1.57)\end{array}$ \\
\hline$\alpha$ & $\begin{array}{l}\mathbf{0 . 0 2} * * \\
(2.39)\end{array}$ & $\begin{array}{l}\text { 0.06**** } \\
(3.19)\end{array}$ & $\begin{array}{c}0.02 \\
(1.57)\end{array}$ \\
\hline$\left(R_{m k t}-R_{f}\right)$ & $\begin{array}{l}\mathbf{0 . 9 6}^{* * * *} \\
(32.13)\end{array}$ & $\begin{array}{l}\mathbf{0 . 9 1} * * * * \\
(14.04)\end{array}$ & $\begin{array}{l}\text { 0.96**** } \\
(31.44)\end{array}$ \\
\hline$S M B$ & $\begin{array}{l}\mathbf{0 . 4 9} * * * * \\
(10.65)\end{array}$ & $\begin{array}{l}\mathbf{0 . 5 3} * * * \\
(6.77)\end{array}$ & $\begin{array}{l}\mathbf{0 . 4 8 * * *} \\
(9.82)\end{array}$ \\
\hline$H M L$ & $\begin{array}{c}0.04 \\
(0.45)\end{array}$ & $\begin{array}{l}\mathbf{0 . 1 9 *} \\
(1.78)\end{array}$ & $\begin{array}{c}0.02 \\
(0.17)\end{array}$ \\
\hline$U M D$ & $\begin{array}{l}\text { 0.16**** } \\
(3.17)\end{array}$ & $\begin{array}{l}-0.09 \\
(-1.38)\end{array}$ & $\begin{array}{l}\mathbf{0 . 2 1} * * * \\
(3.62)\end{array}$ \\
\hline $\begin{array}{l}\text { Avg. Adjusted } R^{2} \\
n\end{array}$ & $\begin{array}{l}23.94 \\
7,856\end{array}$ & $\begin{array}{l}20.41 \\
1,104\end{array}$ & $\begin{array}{l}24.52 \\
6,752\end{array}$ \\
\hline
\end{tabular}

This table presents estimates of trade-specific profits (TradingProfit $t_{i, t}$ ) and coefficients from estimating transaction-day specific regressions of daily returns on common factors over the 180-days following each transaction: $\left(R_{i}-R_{f}\right)=\alpha+\beta_{1}\left(R_{m k t}-R_{f}\right)+\beta_{2} S M B+\beta_{3} H M L+\beta_{4} U M D+e . R_{i}$ is the daily return to firm $i$ 's equity, $R_{f}$ is the daily risk-free interest rate; $R_{m k t}$ is the CRSP value-weighted market return, and $S M B, H M L$, and $U M D$ are the size, book-to-market, and momentum factors (Fama and French, 1993; Carhart, 1997). TradingProfit $t_{i, t}$ is equal to $\alpha(-\alpha)$ for purchases (sales). $t$-statistics appear in parentheses and are based on standard errors clustered by transaction date and firm. ***,**,* denote statistical significance at the 1,5 , and $10 \%$ (two-tail) levels respectively. 
Table 4. Trading Restrictions and Insider Trading Profits

Panel A. All Trades

\begin{tabular}{lcccccr}
\hline \hline & \multicolumn{2}{c}{ Model 1 } & \multicolumn{2}{c}{ Model 2 } & \multicolumn{2}{c}{ Model 3 } \\
& Coeff. & $t$-stat. & Coeff. & $t$-stat. & Coeff. & $t$-stat. \\
\hline Intercept & $\mathbf{0 . 0 3 * *}$ & 2.51 & -0.42 & -0.66 & $\mathbf{0 . 0 2} *$ & 1.89 \\
$G C_{i}$ & $-\mathbf{0 . 0 4} * * *$ & -2.76 & & & $-\mathbf{0 . 0 3} * *$ & -2.33 \\
InWin $_{i, t}$ & & & 0.08 & 0.07 & $\mathbf{0 . 0 4} * *$ & 2.34 \\
$G C_{i}{ }^{*} \operatorname{InWin}_{i, t}$ & & & & & $\mathbf{- 0 . 0 4 * *}$ & -2.02 \\
Adjusted $R^{2}$ & 0.69 & & 0.00 & \multicolumn{2}{c}{0.80} \\
$n$ & 7,856 & 7,856 & \multicolumn{2}{c}{7,856} \\
\hline \hline
\end{tabular}

Panel B. Purchases

\begin{tabular}{|c|c|c|c|c|c|c|}
\hline & \multicolumn{2}{|c|}{ Model 1} & \multicolumn{2}{|c|}{ Model 2} & \multicolumn{2}{|c|}{ "Model 3} \\
\hline & Coeff. & $t$-stat. & Coeff. & $t$-stat. & Coeff. & $t$-stat. \\
\hline Intercept & $0.10 * *$ & 2.38 & $0.03 * * *$ & 2.88 & $0.09 * * *$ & 2.66 \\
\hline$G C_{i}$ & $-0.08 *$ & -1.81 & & & $-0.07 * *$ & -2.08 \\
\hline $\operatorname{InWin}_{i, t}$ & & & 0.03 & 1.49 & 0.04 & 0.68 \\
\hline$G C_{i} * \operatorname{In} \operatorname{Win}_{i, t}$ & & & & & -0.01 & -0.19 \\
\hline $\begin{array}{l}\text { Adjusted } R^{2} \\
n\end{array}$ & \multicolumn{2}{|c|}{$\begin{array}{l}3.01 \\
1.104\end{array}$} & \multicolumn{2}{|c|}{0.40} & \multicolumn{2}{|c|}{3.23} \\
\hline
\end{tabular}

Panel C. Sales

\begin{tabular}{|c|c|c|c|c|c|c|}
\hline & \multicolumn{2}{|c|}{ Model 1} & \multicolumn{2}{|c|}{ Model 2} & \multicolumn{2}{|c|}{ Model 3} \\
\hline & Coeff. & $t$-stat. & Coeff. & $t$-stat. & Coeff. & $t$-stat. \\
\hline Intercept & 0.02 & 1.33 & -0.01 & -1.27 & 0.01 & 0.77 \\
\hline$G C_{i}$ & $-0.03 * *$ & -1.98 & & & -0.02 & -0.14 \\
\hline $\operatorname{InWin}_{i, t}$ & & & -0.001 & -0.04 & $0.04 * * *$ & 2.81 \\
\hline$G C_{i}{ }^{*} \operatorname{In} \operatorname{Win}_{i, t}$ & & & & & $-0.05 * *$ & -2.36 \\
\hline $\begin{array}{l}\text { Adjusted } R^{2} \\
n\end{array}$ & \multicolumn{2}{|c|}{$\begin{array}{c}0.40 \\
6,752\end{array}$} & \multicolumn{2}{|c|}{$\begin{array}{c}0.00 \\
6,752\end{array}$} & \multicolumn{2}{|c|}{$\begin{array}{c}0.50 \\
6,752\end{array}$} \\
\hline
\end{tabular}


Regressions of risk-adjusted trading profits on trading restrictions:

TradingProfit $t_{i, t}=\beta_{0}+\beta_{1} G C_{i}+\beta_{2} \operatorname{InWin}_{i, t}+\beta_{3} G C_{i} * \operatorname{InWin}_{i, t}+\varepsilon_{i, t}$

where $i$ denotes firm, $t$ denotes day. TradingProfit is the average risk-adjusted return for each transaction (in percent) calculated over the 180-days following the transaction and relative to the Fama and French (1993) and Carhart (1997) four factor models. TradingProfit $t_{i, t}$ is equal to $\alpha(-\alpha)$ for purchases (sales), where $\alpha$ is the intercept from the four factor Fama-French (1993) and Carhart (1997) model estimated over the 180 days

subsequent to the transaction (see Table 3). GC equals one if GC approval is required and zero otherwise; and InWin equals one if the trade occurs inside the firm's restricted trading window and zero otherwise. $t$-statistics are based on standard errors clustered by transaction date and firm. ***, **, * denote statistical significance at the 1,5 , and $10 \%$ (two-tail) levels respectively. 


\section{Table 5. Predictive Ability of Insider Trades for Future Operating Performance}

\begin{tabular}{|c|c|c|c|c|}
\hline \multirow[b]{3}{*}{$\begin{array}{l}\text { Independent } \\
\text { Variable }\end{array}$} & \multicolumn{2}{|c|}{$\begin{array}{l}\text { Dependent Variable } \\
\text { Surprise }=\Delta \text { Earn }_{i, q}\end{array}$} & \multicolumn{2}{|c|}{$\begin{array}{l}\text { Dependent Variable } \\
\text { Surprise = Anncret } t_{i, q}\end{array}$} \\
\hline & Model 1 & Model 2 & Model 1 & Model 2 \\
\hline & $\begin{array}{l}\text { Coeff. } \\
(t \text {-stat.) }\end{array}$ & $\begin{array}{c}\text { Coeff } \\
(t \text {-stat })\end{array}$ & $\begin{array}{l}\text { Coeff. } \\
(t \text {-stat.) }\end{array}$ & $\begin{array}{l}\text { Coeff. } \\
(t \text {-stat.) }\end{array}$ \\
\hline NetTrade $_{i, q}$ & $\begin{array}{l}0.48 \\
(1.04)\end{array}$ & & $\begin{array}{c}0.40 \\
(0.77)\end{array}$ & \\
\hline WindowTrade $_{i, q}$ & & $\begin{array}{l}-0.22 \\
(-1.34)\end{array}$ & & $\begin{array}{l}\mathbf{1 . 7 5}^{* * * *} \\
(9.37)\end{array}$ \\
\hline NonWindowTrade $_{i, q}$ & & $\begin{array}{l}\mathbf{1 . 9 0 * * * *} \\
(3.00)\end{array}$ & & $\begin{array}{l}\mathbf{1 . 7 9 * *} \\
(2.45)\end{array}$ \\
\hline$G C_{i}$ & & $\begin{array}{l}-\mathbf{0 . 3 8} * * \\
(-2.31)\end{array}$ & & $\begin{array}{l}-0.50 \\
(-0.97)\end{array}$ \\
\hline$G C_{i} *$ WindowTrade $e_{i, q}$ & & $\begin{array}{l}-0.59 \\
(-1.20)\end{array}$ & & $\begin{array}{l}-\mathbf{2 . 5 5} * * * \\
(-3.49)\end{array}$ \\
\hline$G C_{i} *$ NonWindowTrade $e_{i, q}$ & & $\begin{array}{l}-\mathbf{1 . 8 3} * * * * \\
(-2.89)\end{array}$ & & $\begin{array}{l}-\mathbf{1 . 8 5} * * \\
(-2.48)\end{array}$ \\
\hline$S i z e_{i, q}$ & $\begin{array}{l}-0.06 \\
(-1.18)\end{array}$ & $\begin{array}{l}-\mathbf{- 0 . 1 0 *} \\
(-1.88)\end{array}$ & $\begin{array}{l}-0.01 \\
(-0.09)\end{array}$ & $\begin{array}{l}-0.05 \\
(-0.40)\end{array}$ \\
\hline$B M_{i, q}$ & $\begin{array}{l}-0.39 \\
(-0.93)\end{array}$ & $\begin{array}{l}-0.53 \\
(-1.37)\end{array}$ & $\begin{array}{c}0.70 \\
(0.73)\end{array}$ & $\begin{array}{c}0.68 \\
(0.68)\end{array}$ \\
\hline $\begin{array}{l}\text { Adjusted } R^{2} \\
n\end{array}$ & $\begin{array}{l}4.16 \\
1,945\end{array}$ & $\begin{array}{l}16.58 \\
1,945 \\
\end{array}$ & $\begin{array}{c}0.54 \\
1,945\end{array}$ & $\begin{array}{r}2.59 \\
1,945\end{array}$ \\
\hline
\end{tabular}

Regressions of future operating performance on insider trading and control variables:

Surprise $_{i, q}=\beta_{0}+\beta_{1}$ WindowTrade $_{i, q}+\beta_{2}$ NonWindowTrade $_{i, q}+\beta_{3} G C_{i}+\beta_{4} G C_{i} *$ WindowTrade $_{i, q}$ $+\beta_{5} G C_{i} *$ NonWindowTrade $i, q+\beta_{6}$ Size $_{i, q}+\beta_{7} B M_{i, q}+\varepsilon_{i, q}$

where $i$ denotes firm, $q$ denotes quarter, Surprise $i_{i, q}$ is either $\triangle E a{ }^{2} n_{i, q}$ or Anncret $_{i, q} . \Delta E A R N_{i, q}$ is the earnings surprise for quarter $q$, measured forecast error from seasonal random walk model of quarterly earnings (data \#8) scaled by total assets (data \#44) and in percent. Anncret ${ }_{q}$ is the earnings announcement period return for quarter $q$, measured as the three-day market-adjusted buy-and-hold return centered on the earnings announcement date in percent. WindowTrade is the net insider trade within the restricted trade window over the 90 days prior to the earnings announcement (volume of buys within the window less volume of sales within the window, as a percent of shares outstanding) and NonWindowTrade is the net insider trade outside the restricted trade window over the 90 days prior to the earnings announcement (volume of buys outside the window less volume of sales outside the window, as a percent of shares outstanding), NetTrade $q$ is the net insider trade over the 90 days prior to the earnings announcement (the sum of WindowTrade and NonWindowTrade). GC equals one if GC approval is needed to execute the trade and equals zero otherwise. Size $e_{q}$ is the natural $\log$ of market value at the end of the fiscal quarter. $B M_{q}$ is book value (data \#59) scaled by market value at the end of the quarter. $t$-statistics appear in parentheses and are based on standard errors clustered by quarter and firm. ***,**, * denote statistical significance at the 1,5 , and $10 \%$ (two-tail) levels respectively. 
Table 6. Propensity Score Matched Sample

Panel A. Probability of GC Approval

\begin{tabular}{lrr}
\hline \hline & \multicolumn{2}{c}{ Model 1 } \\
\cline { 2 - 3 } Dep Var = GC & Coeff. & $t$-stat. \\
InsChair & -0.35 & -1.31 \\
LeadOutsDir & 0.36 & 1.46 \\
InsidDirs\% & -0.53 & -0.54 \\
AffilDirs\% & 0.03 & 0.04 \\
Restatements & $\mathbf{- 2 . 0 8 * *}$ & -2.36 \\
Blockholders & 0.18 & 0.94 \\
Analysts & $\mathbf{- 0 . 4 8 * *}$ & -2.53 \\
EarnVol & -0.27 & -1.06 \\
IdioVol & 4.07 & 0.54 \\
Size & $\mathbf{0 . 2 1 *}$ & 1.87 \\
BM & $\mathbf{- 0 . 9 0 * * *}$ & -2.77 \\
& & \\
Pseudo $R^{2}$ & & 8.50 \\
Overall $\chi^{2}$ & & 22.01 \\
$n$ & & 260 \\
\hline \hline
\end{tabular}

Panel B. Covariate Balance: Propensity Score Matched Sample

\begin{tabular}{|c|c|c|c|c|c|c|c|}
\hline & \multicolumn{2}{|c|}{$\begin{array}{l}\text { GC Approval } \\
\text { Required }\end{array}$} & \multicolumn{2}{|c|}{$\begin{array}{l}\text { GC Approval } \\
\text { Not Required }\end{array}$} & \multirow{2}{*}{$\begin{array}{l}\begin{array}{l}\text { Diff in } \\
\text { Means }\end{array} \\
t \text {-stat. }\end{array}$} & \multirow{2}{*}{$\begin{array}{c}\text { Diff in } \\
\text { Medians } \\
\text { Wilcoxon } \\
p \text {-value }\end{array}$} & \multirow{2}{*}{$\begin{array}{c}\text { Diff in } \\
\text { Distributions } \\
\mathrm{KS} \\
p \text {-value }\end{array}$} \\
\hline & Mean & Median & Mean & Median & & & \\
\hline Size & 6.41 & 6.34 & 6.47 & 6.65 & -0.17 & 0.840 & 0.420 \\
\hline$B M$ & 0.61 & 0.59 & 0.60 & 0.53 & 0.12 & 0.600 & 0.730 \\
\hline InsChair & 0.72 & 1.00 & 0.73 & 1.00 & -0.02 & 0.940 & 0.990 \\
\hline LeadOutsDir & 0.41 & 0.50 & 0.37 & 0.50 & 0.51 & 0.460 & 0.570 \\
\hline InsidDirs\% & 0.21 & 0.16 & 0.20 & 0.15 & 0.52 & 0.550 & 0.200 \\
\hline AffilDirs\% & 0.14 & 0.10 & 0.13 & 0.11 & 0.06 & 0.930 & 0.880 \\
\hline Restatements & 0.07 & 0.00 & 0.07 & 0.00 & 0.00 & 0.810 & 0.990 \\
\hline Blockholders & 0.93 & 1.10 & 0.95 & 1.00 & -0.22 & 0.970 & 0.570 \\
\hline Analysts & 1.72 & 1.71 & 1.73 & 1.75 & -0.05 & 0.780 & 0.570 \\
\hline EarnVol & 0.17 & 0.07 & 0.18 & 0.08 & -0.85 & 0.720 & 0.250 \\
\hline IdioVol & 0.02 & 0.02 & 0.03 & 0.02 & -1.27 & 0.680 & 0.420 \\
\hline
\end{tabular}


Table 6. Propensity Score Matched Sample (cont'd)

\section{Panel C. Insider Trading Returns: Propensity Score Matched Sample}

\begin{tabular}{|c|c|c|c|c|c|c|c|}
\hline & \multicolumn{2}{|c|}{$\begin{array}{l}\text { GC Approval } \\
\text { Required }\end{array}$} & \multicolumn{2}{|c|}{$\begin{array}{l}\text { GC Approval } \\
\text { Not Required }\end{array}$} & \multirow{2}{*}{$\begin{array}{l}\text { Diff in } \\
\text { Means } \\
t \text {-stat. }\end{array}$} & \multirow{2}{*}{$\begin{array}{c}\text { Diff in } \\
\text { Medians } \\
\text { Wilcoxon } \\
p \text {-value } \\
\end{array}$} & \multirow{2}{*}{$\begin{array}{c}\text { Diff in } \\
\text { Distributions } \\
\text { KS } \\
p \text {-value } \\
\end{array}$} \\
\hline & Mean & Median & Mean & Median & & & \\
\hline \multicolumn{8}{|l|}{ All Trades } \\
\hline TradingProfit & 0.01 & 0.01 & 0.03 & 0.02 & $2.05 * *$ & $0.002 * * *$ & $0.003 * * *$ \\
\hline \multicolumn{8}{|c|}{ Trade Within a Restricted Window } \\
\hline TradingProfit & 0.03 & 0.02 & 0.07 & 0.05 & $1.98 * *$ & $0.04 * *$ & $0.002 * * *$ \\
\hline
\end{tabular}

Panel A presents results from estimating:

$$
\operatorname{Pr}(G C=1)=\frac{1}{1+e^{-\beta X}},
$$

where $\beta X=\alpha_{0}+\alpha_{1}$ InsChair $+\alpha_{2}$ LeadOutsDir $+\alpha_{3}$ InsDirs $\%+\alpha_{4}$ AffilDirs $\%+\alpha_{5}$ Blockholders $+\alpha_{6}$ Analysts + $\alpha_{7}$ Restatements $+\alpha_{8}$ EarnsVol $+\alpha_{9}$ RetVol $+\varepsilon$.

$G C$ equals one if the firm requires GC approval for trades and equals zero otherwise. InsChair equals one if Equilar denotes the board chairman as a firm officer during both 2004 and 2005, equals 0.5 if the board chairman is denoted a firm officer during one but not both of years 2004 and 2005, and equals zero otherwise. LeadOutsDir equals one if Equilar denotes a lead outside director during both 2004 and 2005, equals 0.5 if a lead outside director is denoted during one but not both of years 2004 and 2005, and equals zero otherwise. InsidDirs\% is the ratio of Equilardenoted officer-directors to total directors, averaged across 2004 and 2005. AffilDirs\% is the ratio of Equilardenoted affiliated-directors to total directors, averaged across 2004 and 2005. Restatements is the percent of years between 2001 and 2005 during which Glass-Lewis denotes the firm made an accounting restatement. Blockholders is the log of one plus the number of CDA/Spectrum-denoted 5\% institutional blockholders, averaged across 2004 and 2005. Analysts is the log of one plus the number of analysts providing estimates of one-year-ahead earnings forecasts on I/B/E/S, averaged across 2004 and 2005. EarnsVol is the standard deviation of the ratio of annual net income to beginning assets, for years 1996 through 2005. IdioVol is the standard deviation of daily returns in excess of the CRSP value-weighted market portfolio, for years 2004 and 2005. Size is the natural log of market value measured quarterly and averaged over the sample period. $B M$ is the ratio of book value of equity to market value of equity measured quarterly and averaged over the sample period. $* * *, * * *$ denote statistical significance at the 1,5 , and $10 \%$ (two-tail) levels respectively.

Panel B presents the difference in means, medians, and distributions between the treatment and control samples for governance and information asymmetry variables. Panel $\mathrm{C}$ presents the difference in means, medians, and distributions between the treatment and control samples for insider trading profits. Treatment and control samples are formed by matching each firm that does not require GC approval (control sample) to a single firm that requires GC approval (treatment sample) using propensity score matching. The propensity score is the predicted probability of GC approval using the model estimated in Panel A. $t$-statistics appear in parentheses and test for a difference in means between treatment and control samples, Wilcoxon $p$-values appear in brackets and test for a difference in medians, and Kolmogorov-Smirnov (KS) $p$-values appear in brackets and test for a difference in distributions. ***, $* *, *$ denote statistical significance at the 1,5 , and $10 \%$ (two-tail) levels respectively. 